\title{
Current Research: A Pilot Study in the Use of pXRF Analysis of Caddo Ceramics
}

Tom Middlebrook

Heritage Research Center, Stephen F. Austin State University

C. Colleen Hanratty

University of Texas at Tyler

Follow this and additional works at: https://scholarworks.sfasu.edu/ita

Part of the American Material Culture Commons, Archaeological Anthropology Commons, Environmental Studies Commons, Other American Studies Commons, Other Arts and Humanities Commons, Other History of Art, Architecture, and Archaeology Commons, and the United States History Commons

Tell us how this article helped you.

This Article is brought to you for free and open access by the Center for Regional Heritage Research at SFA ScholarWorks. It has been accepted for inclusion in Index of Texas Archaeology: Open Access Gray Literature from the Lone Star State by an authorized editor of SFA ScholarWorks. For more information, please contact cdsscholarworks@sfasu.edu. 


\section{Current Research: A Pilot Study in the Use of pXRF Analysis of Caddo Ceramics Creative Commons License \\ (c) (1) \& 8}

This work is licensed under a Creative Commons Attribution-NonCommercial 4.0 International License 


\title{
Current Research: A Pilot Study in the Use of pXRF Analysis of Caddo Ceramics
}

\author{
Tom Middlebrook ${ }^{1}$ and C. Colleen Hanratty ${ }^{2}$ \\ ${ }^{1}$ Texas Archeological Stewardship Network, ${ }^{2}$ University of Texas at Tyler
}

Wilson "Dub" Crook III's (2018) paper presented to the East Texas Archeological Conference concerning the use of X-ray Fluorescence (XRF) in sourcing turquoise artifacts sparked an interest in utilizing $\mathrm{pXRF}$ to resolve an old Caddo ceramic research question. While XRF has been used in archaeology for more than 60 years (Shackley 2011:1), and there have been applications in ceramic studies (Shackley 2012; Ownby 2012; Hunt and Speakman 2015; Forster et al. 2011; Speakman et al. 2011; Shugar and Mass 2012), a recent review of the 9th Edition of The Archaeology, Bioarchaeology, Ethnohistory, and History of the Caddo Indian Peoples of Arkansas, Louisiana, Oklahoma, and Texas (Perttula 2019), a comprehensive bibliography, did not yield a single reference to a pXRF study in Caddo ceramics. This article will summarize: (1) the research question arising from work at the Morse Mound Site (41SY27), (2) an overview of how pXRF works, and (3) the data analysis from this pilot study.

In January and February 2000, archaeologists

from the Texas Historical Commission and the Texas Archeological Stewardship Network excavated portions of two Caddo earthen mounds at the Morse Mound site near Center, Texas (Bruseth et al. 2000; Middlebrook 2014). The larger mound (Mound A) was a low conical mound standing 1.0 meter $(\mathrm{m})$ high and $15 \mathrm{~m}$ in diameter. Beneath this mound was the posthole outline of a $5.6 \mathrm{~m}$ round house containing a central $3.6 \mathrm{~m}$ round shaft tomb of an important elite individual. Evidence suggested that the house had been burned and pushed into the pit after interment and partial filling of the pit. The building, perhaps the residence of the deceased elite, and the tomb, were commemorated with the construction of the mound. The acidic soil chemistry at the site led to the complete dissolution of all skeletal and dental remains. Interestingly, most of the perishable materials placed in the grave such as wooden boxes, baskets, matting, arrow shafts, and cordage were replaced by a distinct fine gray silty material. Inside the outline of the Caddo elite's coffin was a $25.6 \mathrm{~cm}$ long Anderson knife, two carved stone earspools, and two sets of Bassett points $(n=20$, and $n=15)$. Just outside the coffin and to the individual's upper left was a small gray silty area containing another quiver of Bassett points $(n=8)$, two carved stone earspools, and a clay pipe. This latter collection may have represented the interment of a second individual or the placement of a sacred bundle. Outside of the coffin and to the interred persons' right side were 11 ceramic vessels: two Glassell Engraved globular bottles with long necks, four Tyson Engraved bowls, a Broaddus Brushed jar, a Belcher Ridged jar, an untyped brushed jar, an untyped pinched jar, and an elongated Hume Engraved bottle. This last vessel was in poor condition due to its very soft surface and could not be fully reconstructed (Figure 1). From the time of its initial assessment, this "Index Vessel" was considered to have been a possible trade item from a Frankston phase Caddo community in the Upper Neches region, some 75 miles to the west. This speculation was based on its distinctive vessel form, engraved decoration, and its soft, orangish exterior surface. All the other fine ware vessels from the Morse Mound site are from vessel types that are known from other Shelby County sites. In order to obtain additional comparative compositional data bearing on the question of the vessel's trade status, all ceramic objects from the Morse Mound shaft tomb were subject to pXRF analysis done at the University of Texas at Tyler in February 2019.

$\mathrm{X}$-ray fluorescence analysis determines the qualitative elemental composition of an object and may provide quantitative data in parts-per-million. Hand-held portable Energy-Dispersive XRF instrumentation has multiple advantages: (1) the potential for being nondestructive to the studied object, (2) minimal preparation to study an object, (3) fast data recovery, (4) ease of use, and (5) cost effectiveness (Shackley 2012:8f). Some 


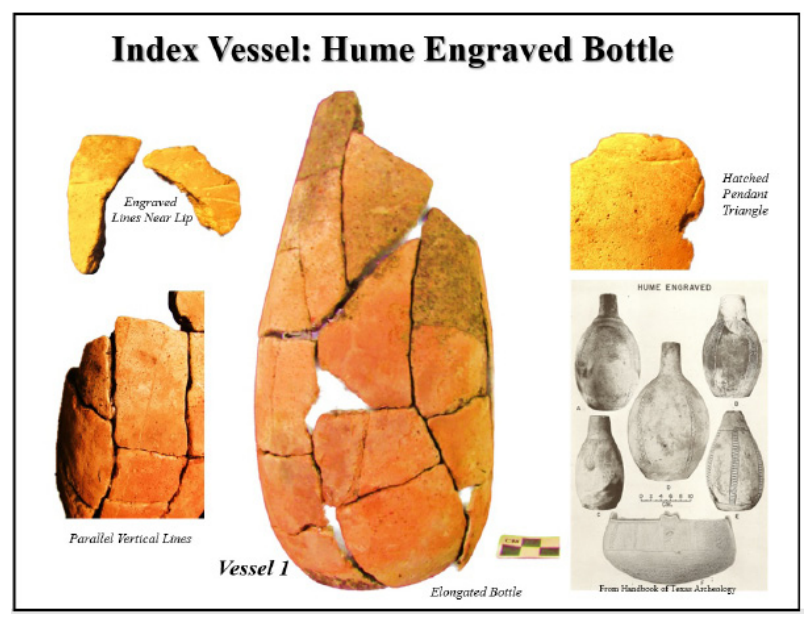

Figure 1. Photos of Vessel 1 (Index Vessel), a Hume Engraved bottle.

limitations of XRF include the need for at least $10 \mathrm{~mm}^{2}$ surface area to study; a minimum thickness of the object is $2 \mathrm{~mm}$; and it is not useful for the lighter elements (typically pXRF is used for mid-range atomic number $\mathrm{Z}=14$ Silicon and above).

X-radition refers to that part of the electromagnetic spectrum intermediate between ultraviolet and gamma radiation (wavelength $=0.03$ $3 \mathrm{~nm}$, frequency $=3 \times 10^{16}-3 \times 10^{19} \mathrm{~Hz}$ ) with energies in the range of $100 \mathrm{eV}$ to $200 \mathrm{keV}$. The $\mathrm{pXRF}$ instrument irradiates the studied object with high energy X-Rays that dislodge electrons from the tightly bond inner shells. When an electron from higher shells drops into the vacated spot to maintain atomic stability, energy is released in the form of an X-ray photon; this is known as X-ray fluorescence. The $\mathrm{K} \alpha$ emission results when an electron fills a spot in the innermost $\mathrm{K}$ shell by an electron from the $2 p$ orbital of the second or L shell; $L \alpha$ refers to an electron falling into the vacancy in the $\mathrm{L}$ shell from the third or $\mathrm{M}$ shell. In addition to sending a beam of X-rays into the studied object, the pXRF instrument contains a detector that measures the energy $(\mathrm{keV})$ of fluorescent $\mathrm{X}$-ray photons emitted by the electron transitions. The $\mathrm{keV}$ of each photon is directly related to the specific element. The detector also measures the emission rates in counts per second (cps), indicating the concentration of the identified element. These two measured factors, energy and emission rates, are the basis of producing an X-ray fluorescence spectrum of any object.
We collected data from each of the Morse Mound ceramic objects with a Burker Tracer III-SD system utilizing a rhodium target X-ray tube as an excitation source and a silicon drift detector with a resolution of approximately $145 \mathrm{eV}$ at 100,000 cps. No filter was used. Data was processed with Bruker's software suite with basic empirical calibration. Data was collected over an area of $10 \mathrm{~mm}^{2}$ for 60 seconds per sample. Two to four (average three) samples were collected per object, typically from smooth spots on the interior surface, exterior surface, and at a patch of exposed paste. The samples from each ceramic object were averaged for comparison and use in development of scatterplots in Microsoft Excel. Peak counts for $\mathrm{K} \alpha$ (and L $\alpha$ in the case of Th) were recorded for 24 elements including silicon, chlorine, argon, potassium, calcium, scandium, titanium, vanadium, chromium, manganese, iron, cobalt, zinc, gallium, arsenic, rubidium, strontium, yttrium, zirconium, niobium, ruthenium, rhodium, cesium, and thorium.

Initially, we selected three elements that had clear peaks on the pXRF spectrum to use for comparisons of the ceramic vessels and pipe: potassium $(\mathrm{K})$, Calcium $(\mathrm{Ca})$, and Iron $(\mathrm{Fe})$. While minor or trace elements are most frequently used in sourcing studies of cherts and many other archaeological materials, we decided in this pilot study to use some of the most common elements that perhaps would distinguish various clays. When the three scatterplots were produced $(\mathrm{Fe} / \mathrm{K}, \mathrm{Fe} / \mathrm{Ca}, \mathrm{K} / \mathrm{Ca}$ ), the Index vessel (V-1) was an outlier on all the plots. Of all 11 ceramic vessels, $\mathrm{V}-1$ had the lowest average $\mathrm{K}$ and $\mathrm{Ca}$ content, and the second highest Fe content. Interestingly, two other objects, namely the pipe and the pinched decorated Vessel 9, clustered with V-1 on all three plots. Both of these items also had the reddish-orange color and softer surface that characterized the Index vessel. Both objects may have been produced in the Upper Neches region as well based on style and decoration (Timothy K. Perttula, personal communication, February 2019). Because the production methodology of Caddo fine wares may differ from utility wares, a set of scatterplots for $\mathrm{Fe} / \mathrm{K}, \mathrm{Fe} / \mathrm{Ca}$, and $\mathrm{K} / \mathrm{Ca}$ were made just looking at the seven fine ware objects. The Index vessel stood out as an outlier in all three cases (Figures 2-4). 


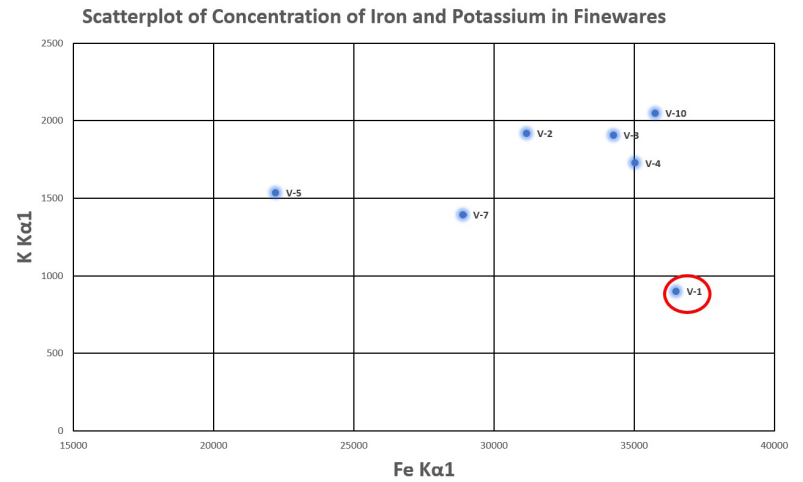

Figure 2. Bivariant Scatterplot of $\mathrm{Fe}$ and $\mathrm{K}$ concentrations in the fine wares.

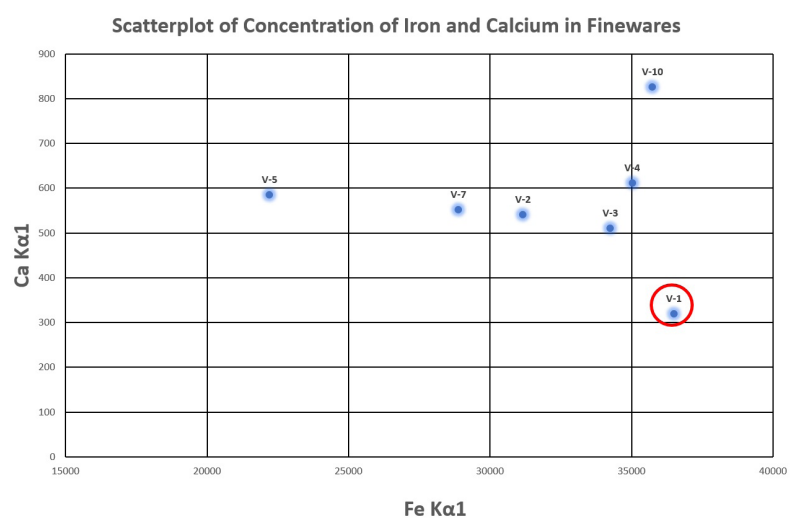

Figure 3. Bivariant Scatterplot of $\mathrm{Fe}$ and $\mathrm{Ca}$ concentrations in the fine wares.

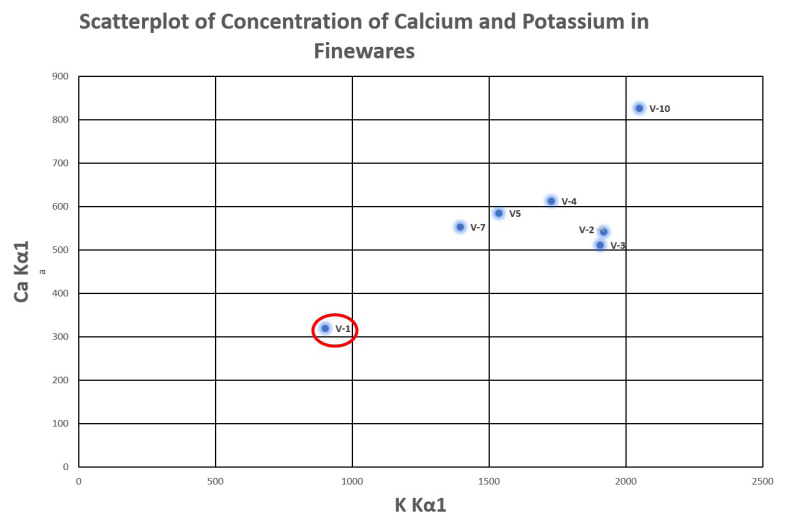

Figure 4. Bivariant Scatterplot of $\mathrm{K}$ and $\mathrm{Ca}$ concentrations in the fine wares.
Ferguson (2010) reanalyzed the Texas Caddo Neutron Activation Analysis database from nine designated drainage basins in East Texas. (Shelby County sites fall in the study's Region 9, and the Upper Neches sites are within Region 8). His research employed bivariant scatterplots of $\mathrm{Fe}$ and 10 other trace elements (cesium, chromium, arsenic, hafnium, titanium, antimony, vanadium, lutetium, cerium, and thorium). Utilizing two elements, namely chromium and arsenic, helpful in analyzing sites within Region 8 in Ferguson's study, we constructed a scatterplot of the seven Morse Mound fine ware vessels to see if trace elements could provide helpful information regarding compositional distinctions between our Index vessel and others thought to be locally made. Again, the data from V-1 was an outlier (Figure 5).

This small pilot study is one of the first to use pXRF in Caddo ceramic research. It proved to be a rapid, non-destructive, and inexpensive method for generating elemental composition data regarding Caddo pottery. The results generally supported the notion that Vessel 1 was not typical of most of the other ceramic items in the Morse Mound shaft tomb and may represent a trade item. The pipe and Vessel 9 appear compositionally similar to the Index vessel and may have derived from a similar production location. Additional pXRF data from known ceramics from the Upper Neches region will be needed to confirm a compositional similarity of Vessel 1 with Frankston phase ceramic assemblages.

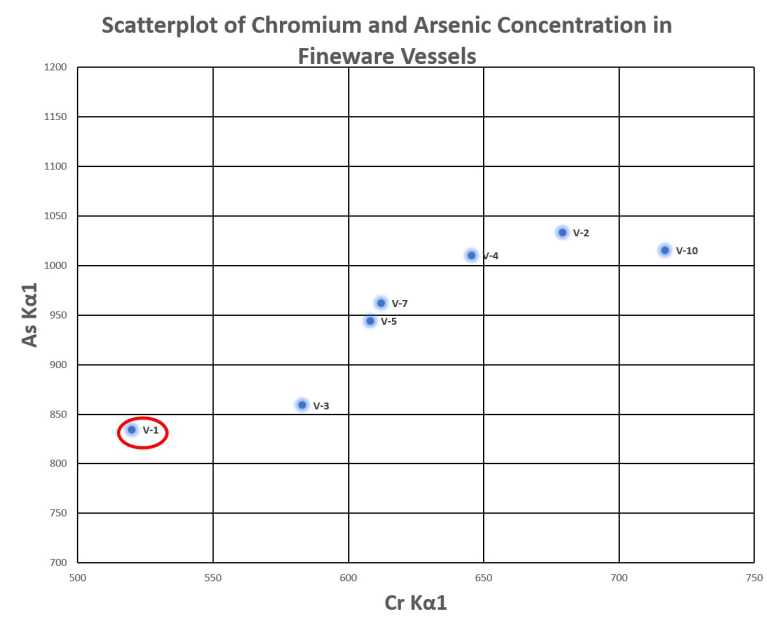

Figure 5. Bivariant Scatterplot of $\mathrm{Cr}$ and As concentrations in the fine wares. 
The limitations of this study are numerous. In future studies, many more samples or counts from each object would be needed. We propose that six to eight readings be taken for each ceramic item, perhaps dropping the high and low count, and averaging the remaining ones. This seems prudent in complex, tempered, heterogenous objects like Caddo pottery. Beyond the basic counts used for comparison, full quantitative data in parts-per-million need to be recorded. Dub Crook (personal communication, February 24-26, 2019) kindly provided useful feedback shortly after this paper was originally presented. He suggested: (1) longer counts, perhaps 300 seconds; (2) use of freshly broken surface for taking readings in the core of the ceramic objects while also taking into consideration the effects of groundwater deposition on exterior surfaces; (3) focus on minor and trace elements for comparison; and (4) the development of a meaningful regional sherd and clay database for analytic comparison.

\section{References Cited}

Bruseth, J., M. Parsons, T. Middlebrook, and B. Martin 2000 Unprecedented Find Uncovered at the Ronald and Kay Morse Site (41SY27). Current Archeology in Texas 2(1):4-7.

Ferguson, J. R.

2010 Preliminary Report on the Reanalysis of the Texas Caddo NAA Database. In Studies on the Instrumental Neutron Activation Analysis of Woodland Period and Caddo Tradition Ceramics from Eastern Texas, compiled by T. K. Perttula, Article 1. Special Publication No. 17. Friends of Northeast Texas Archaeology, Austin and Pittsburg.

Forster, N., P. Grave, N. Vickery, and L. Kealhofer 2011 Non-Destructive Analysis Using PXRF: Methodology and Application to Archaeological Ceramics. X-Ray Spectrometry 40(5):389-398.
Hunt, A. and R. Speakman

2015 Portable XRF Analysis of Archaeological sediments and Ceramics. Journal of Archaeological Science 53:1-13.

Middlebrook, T.

2014 Early European Descriptions of Hasinai Elites and Understanding Prehistoric Caddo Mortuary Practices in Shelby County, Texas. Bulletin of the Texas Archeological Society 85:83-110.

Ownby, M.F.

2012 The Use of Portable X-ray Fluorescence Spectrometry for Analyzing Ancient Ceramics. Archaeology Southwest Magazine 26(2), www. archaeologicalsouthwest.org/asw26-2.

Perttula, T. K. (editor)

2019 9th Edition of the Archaeology, Bioarchaeology, Ethnography, Ethnohistory, and History of the Caddo People of Arkansas, Louisiana, Oklahoma, and Texas. Special Publication No. 54. Friends of Northeast Texas Archaeology, Austin and Pittsburg.

Shackley, M. S.

2012 Portable X-ray Fluorescence Spectrometry (pXRF): The Good, the Bad, and the Ugly. Archaeology Southwest Magazine 26(2), www. archaeologicalsouthwest.org/asw26-2.

Shackley, M. S. (editor)

2011 X-Ray Fluorescence Spectrometry (XRF) in Geoarchaeology. Springer, New York.

Shugar, A. N. and J. L. Mass (editors)

2012 Studies in Archaeological Sciences: Handheld $X R F$ for Art and Archaeology. Leuven University Press, Leuven.

Speakman, R., N. Little, D. Creel, M. Miller, and J. Iñañez

2011 Sourcing Ceramics with Portable XRF Spectrometers? A Comparison with INAA using Mimbres Pottery from the American Southwest. Journal of Archaeological Science 38:3483-3496. 